Article

\title{
The Effect of Different Doses of Sewage Sludge and Liming on Total Cobalt Content and its Speciation in Soil
}

\author{
Elżbieta Malinowska *D and Kazimierz Jankowski \\ Faculty of Agrobioengineering and Animal Husbandry, Siedlce University of Natural Sciences and Humanities, \\ Prusa 14 Street, 08-110 Siedlce, Poland; kazimierz.jankowski@uph.edu.pl \\ * Correspondence: elzbieta.malinowska@uph.edu.pl; Tel.: +48-25-6431319
}

Received: 25 August 2020; Accepted: 8 October 2020; Published: 11 October 2020

check for updates

\begin{abstract}
The aim of this paper is to evaluate the effect of liming and various doses of municipal sewage sludge $(5,10$, and $15 \%$ of the weight of the soil) on cobalt total content and its speciation. The incubation experiment lasted 420 days and was conducted in controlled laboratory conditions. Soil was sampled after 30,60, 90, and 120 days and then, with a break of 180 days, after 360 and 420 days. In all samples, cobalt total content was determined by means of ICP-AES (emission spectrophotometer), and fractions of this metal were measured with the seven-step Zeien and Brümmer method, with seven of them separated: F1-easily soluble, F2-exchangeable, F3-bound to MnOx, F4-bound to organic matter, F5-bound to amorphous FeOx, F6-bound to crystalline FeOx, and F7-residual. Compared to the control, the average content of total cobalt in the soil increased more than two times in experimental units with higher doses of sewage sludge (10\% and $15 \%$ of the weight of the soil). The metal was mainly bound to the residual fraction, where it constituted $40 \%$ of its total content, while in the organic fraction, its share was $20 \%$. In the soil incubated with sludge, cobalt in mobile fractions constituted a small percentage of its total content. Liming limited the release of this metal.
\end{abstract}

Keywords: cobalt; sludge; soil sequential analysis; the Zeien-Brümmer method

\section{Introduction}

Due to the intensive development of wastewater treatment plants in Poland, the problem of municipal sewage sludge disposal is constantly increasing [1]. Sewage sludge, in addition to food scraps, sand, and fat, is the main by-product of wastewater treatment processes, accounting for the largest share of the suspended solids ( $66.7 \%$ of the volume of wastewater). In accordance with Chapter 2 of Article 3 Point 4 of the Polish Waste Act [2], municipal sewage sludge is defined as the material from fermentation chambers of wastewater treatment plants and other urban wastewater treatment facilities. This waste is a rich source of nutrients [3-5] but also a serious source of mineral and organic pollutants [6-9]. The chemical composition of municipal sewage sludge varies greatly, due to different types of wastewater fed into the treatment plant, different shares of industrial wastewater, and different treatment processes. Heavy metals found in municipal sewage sludge may come from water for domestic purposes, rainwater, or meltwater entering sewerage systems from urban, industrial, and storage areas and, in particular, from transport bases and roads and from car parks with a paved surface [10]. Of the heavy metals present in municipal sewage sludge, cobalt deserves special attention due to its toxicity and the complexity of its soil sorption. There are few reports in the literature on its speciation.

Cobalt activity is dependent on soil conditions and its speciation is most heavily affected by soil $\mathrm{pH}$, texture, redox potential, and mineral and organic colloids [11,12]. It has been found [13,14] that 
liming treatment increasing $\mathrm{pH}$ in the soil is often the main factor affecting its $\mathrm{C}$ to $\mathrm{N}$ ratio and the process of organic matter decomposition. In the natural environment, cobalt occurs most often in the form of $\mathrm{Co}^{2+}, \mathrm{Co}^{3+}$, and $\mathrm{Co}(\mathrm{OH})^{3-}$ ions $[15,16]$.

Adversely affecting soil biological activity, excessive amounts of cobalt, and other heavy metals all have a negative impact on the growth and development of crops and on animals feeding on them; consequently, the quantity and quality of agricultural products is also lowered [17-19].

The total content of heavy metals in the environment is not a sufficient criterion for their toxicity assessment as the degree of their mobility also has to be determined [20]. It is most commonly done using sequential chemical extraction [21-26]. This is a method of isolating mobile fractions of a given metal and its stable forms that are not available to plants.

Sequential chemical extraction is increasingly used for testing soil contaminated either with heavy metals or with waste, containing their elevated amounts [22-26]. According to many authors $[15,27,28]$, in favorable soil condition, plant roots may affect the complexion or dissolution of heavy metals by secreting a variety of substances. That is why, to eliminate the impact of roots on heavy metal speciation, the present incubation experiment was conducted without plants, with $\mathrm{CaCO}_{3}$, and with different doses of sewage sludge applied to soil in containers.

The aim of the experiment was to evaluate the effect of liming and different doses of sewage sludge on total content and speciation of cobalt in soil.

\section{Materials and Methods}

The incubation experiment with three replications was carried out for 420 days in laboratory conditions. The experiment was conducted in a laboratory of the University of Natural Sciences and Humanities in Siedlce, Poland, between 2014 and 2015. The containers were filled with $3 \mathrm{~kg}$ of soil taken from the humus layer, with the granulometric composition of light sandy clay loam (Polish Society of Soil Science, Poland), with a $\mathrm{pH}_{\mathrm{KCl}}$ value of 4.30 . The determination of the soil reaction was made using the potentiometric method, measuring the $\mathrm{pH}$ of the soil suspension in $1 \mathrm{M} \mathrm{KCl}$. The share of individual mineral particles $(\mathrm{mm})$ ranged as follows: from 1 to $0.1-60 \%$; from 0.1 to $0.05-7 \%$; from 0.05 to $0.02-17 \%$; from 0.02 to $0.06-10 \%$; from 0.06 to $0.002-6 \%$. The soil was collected from fields of local farmers. Total content of heavy metals in the soil before the experiment started was as follows $\left(\mathrm{mg} \mathrm{kg}^{-1}\right): \mathrm{Pb}-6.03 ; \mathrm{Cd}-1.02 ; \mathrm{Cr}-2.09 ; \mathrm{Cu}-2.21 ; \mathrm{Zn}-19.95 ; \mathrm{Ni}-1.56$. The above quantities were lower than the limits set by the Regulation of Ministry of the Environment [29] for light soil treated with sewage sludge. The carbon content of organic compounds in the soil was $10.1 \mathrm{~g} \mathrm{~kg}^{-1} \mathrm{dry}$ matter (DM) with $1.58 \mathrm{~g} \mathrm{~kg}^{-1} \mathrm{DM}$ of calcium.

Before filling the containers, the soil was strained through a $0.20 \mathrm{~mm}$ sieve and divided into two parts, one without liming, while the other was limed with $\mathrm{CaCO}_{3}$, according to the hydrolytic acidity, Kappen method. Reagent-grade calcium carbonate $\left(\mathrm{CaCO}_{3}\right)$ at a dose of $3 \mathrm{~g}$ per pot was applied. It was pure anhydrous calcium carbonate), the distributor of which was TechlandLab Ltd., Tarnobrzeg, Poland. Next, the soil was left for 1 month until it reached $50-60 \%$ of its maximum water holding capacity. Two series were obtained this way: without liming (soil not limed) and with liming (limed soil). The sludge came from the municipal mechanical-biological wastewater treatment plant in Siedlce, Poland. It was applied in quantities of 5, 10, and 15\% of the weight of the soil, with 150, 300, or $450 \mathrm{~g}$ of sludge applied to one container, and the contents were mixed thoroughly. Fresh sewage sludge was mixed with soil by hand so that the mixture was homogeneous. The content of selected heavy metals (Table 1) did not exceed the standards provided by the regulation of the Minister of the Environment [30]. However, there were high amounts of total nitrogen and total organic carbon in the sewage sludge. 
Table 1. Concentration of chemical elements and $\mathrm{pH}$ of the sludge.

\begin{tabular}{|c|c|c|c|c|c|c|c|c|c|c|c|}
\hline \multirow{2}{*}{$\mathrm{pH}$} & DM \% & $\begin{array}{c}\text { Organic } \\
\text { Carbon } C_{\text {org }}\end{array}$ & $\begin{array}{c}\text { Total Nitrogen } \\
\mathbf{N}_{\text {tot }}\end{array}$ & \multirow{2}{*}{$\mathrm{C}: \mathrm{N}$} & Co & $\mathrm{Pb}$ & $\mathrm{Cd}$ & $\mathrm{Cr}$ & $\mathrm{Cu}$ & $\mathrm{Zn}$ & $\mathrm{Ni}$ \\
\hline & & \multicolumn{2}{|c|}{$\mathrm{g} \mathrm{kg}^{-1}$} & & \multicolumn{7}{|c|}{$\mathrm{mg} \mathrm{kg}^{-1}$} \\
\hline 6.8 & 25.0 & 345 & 40 & $8.6: 1$ & 3.80 & 50.23 & 0.165 & 19.85 & 85.0 & 1120 & 50.14 \\
\hline
\end{tabular}

In the experiment, there were two control units: one without sludge and without liming and the other without sludge but with $\mathrm{CaCO}_{3}$ applied. During the experiment, soil moisture was maintained at $50-60 \%$ of the maximum water holding capacity and air temperature varied from 20 to $22{ }^{\circ} \mathrm{C}$. Soil samples were collected every 30 days (after 30, 60, 90, and 120 days). There was then a 180-day break, while the soil moisture and air temperature were maintained at the same level as before. Next, the soil was sampled twice with an interval of 60 days, i.e., on the 360th and 420th days of the experiment. Soil samples were collected from each pot using a gouge auger. A representative sample was obtained by mixing 3 individual subsamples collected from the same pot. In all soil samples, cobalt content was determined after dry mineralization at a temperature of $450{ }^{\circ} \mathrm{C}$ by means of the emission spectrophotometer (ICP-AES) method. The fractions of this metal were established using the seven-step Zeien and Brümmer method [31] (Table 2).

Table 2. Sequential extraction of heavy metals with the Zeien-Brümmer method.

\begin{tabular}{|c|c|c|c|c|}
\hline Fraction & Name & Extraction Reagent & Extraction Time & $\mathrm{pH}$ \\
\hline $\mathrm{F} 1$ & easily soluble & $1 \mathrm{~mol} \mathrm{NH}_{4} \mathrm{NO}_{3} \mathrm{dm}^{-3}$ & $24 \mathrm{~h}$ & neutral \\
\hline F2 & exchangeable & $1 \mathrm{~mol} \mathrm{CH}_{3} \mathrm{COONH}_{4} \mathrm{dm}^{-3}$ & $24 \mathrm{~h}$ & 6.0 \\
\hline F3 & bound to $\mathrm{MnO}_{\mathrm{x}}$ & $\begin{array}{c}1 \mathrm{~mol} \mathrm{NH}_{2} \mathrm{OH} \mathrm{HCl} \mathrm{dm} \\
\mathrm{mol} \mathrm{CH}_{3} \mathrm{COONH}_{4} \mathrm{dm}^{-3}\end{array}$ & $0.5 \mathrm{~h}$ & 6.0 \\
\hline $\mathrm{F} 4$ & bound to organic matter & $0.025 \mathrm{~mol} \mathrm{C}_{10} \mathrm{H}_{22} \mathrm{~N}_{4} \mathrm{O}_{8} \mathrm{dm}^{-3}$ & $1.5 \mathrm{~h}$ & 4.6 \\
\hline F5 & bound to amorphous $\mathrm{FeO}_{\mathrm{x}}$ & $\begin{array}{c}0.2 \mathrm{~mol}\left(\mathrm{NH}_{4}\right)_{2} \mathrm{C}_{2} \mathrm{O}_{4} \mathrm{dm}^{-3}+ \\
0.2 \mathrm{~mol} \mathrm{H}_{2} \mathrm{C}_{2} \mathrm{O}_{4} \mathrm{dm}^{-3}\end{array}$ & $4 \mathrm{~h}$ & 3.25 \\
\hline F6 & bound to crystalline $\mathrm{FeO}_{\mathrm{x}}$ & $\begin{array}{c}0.2 \mathrm{~mol}\left(\mathrm{NH}_{4}\right)_{2} \mathrm{C}_{2} \mathrm{O}_{4} \mathrm{dm}^{-3}+ \\
0.2 \mathrm{~mol} \mathrm{H}_{2} \mathrm{C}_{2} \mathrm{O}_{4} \mathrm{dm}^{-3}+0.1 \\
\mathrm{~mol} \mathrm{C}_{6} \mathrm{H}_{8} \mathrm{O}_{6} \mathrm{dm}^{-3}\end{array}$ & $0.5 \mathrm{~h}$ & 3.25 \\
\hline F7 & residual & $\begin{array}{l}\text { Calculated as the difference } \\
\text { between the total content of } \\
\text { cobalt and the sum of the } \\
\text { above determined fractions }\end{array}$ & - & - \\
\hline
\end{tabular}

The proportion of soil to solution-1 g: $10 \mathrm{~cm}^{3}$.

\section{Statistical Analysis}

The results were statistically processed. Analysis of variance was used to determine whether differences between mean values were significant. In the case of significant differences, Tukey's test was applied $\left(\mathrm{LSD}_{0.05}\right)$ to compare the means. Additionally, the Statistica program, Version 10.0 StatSoft [32], was used. Finally, linear correlation coefficients between $\mathrm{pH}$ and total cobalt content and cobalt fractions in the soil were calculated.

\section{Results and Discussion}

The overall cobalt content of the sewage sludge was quite low, at $3.80 \mathrm{mg} \mathrm{kg}^{-1} \mathrm{DM}$ (Table 1). Bojakowska et al. [33] reported similar content of this metal in municipal sewage sludge, ranging from 1 to $7 \mathrm{mg} \mathrm{kg}^{-1} \mathrm{DM}$. Because cobalt content of the sewage sludge is low, there are few scientific reports, unlike in the case of other heavy metals, on its speciation in this residual material, as well as in the soil environment. 
Cobalt sequential analysis indicated that, in municipal sewage sludge, the percentage of its fractions varied widely (Figure 1). It was found that most cobalt (over 40\%) was in the least available residual fraction (F7). Additionally, cobalt bound to organic matter constituted more than $20 \%$ of its overall content. In municipal sludge, metalorganic compounds usually constitute a big percentage of the total content $[34,35]$. The formation of metalorganic compounds in sewage sludge is the result of direct metal-carbon bonding. Such bonds are polarized covalent bonds [36]. In the easy soluble (F1) and exchangeable (F2) fractions, only a small share of cobalt was found (2.3\%). According to Bożym and Rajmund [37], the amount of cobalt soluble forms in test material depends on the type and concentration of the solvent. Wang et al. [38] found varied content of each of the heavy metals in the residual fraction using the Community Bureau of Reference-BCR method. It was also found [39-41] that cobalt is easily sorbed by organic substances and forms organic chelates, which increase its mobility and affect its movement in the soil profile, increasing its uptake by plants. In a reducing environment, cobalt was easily soluble and available to plants.

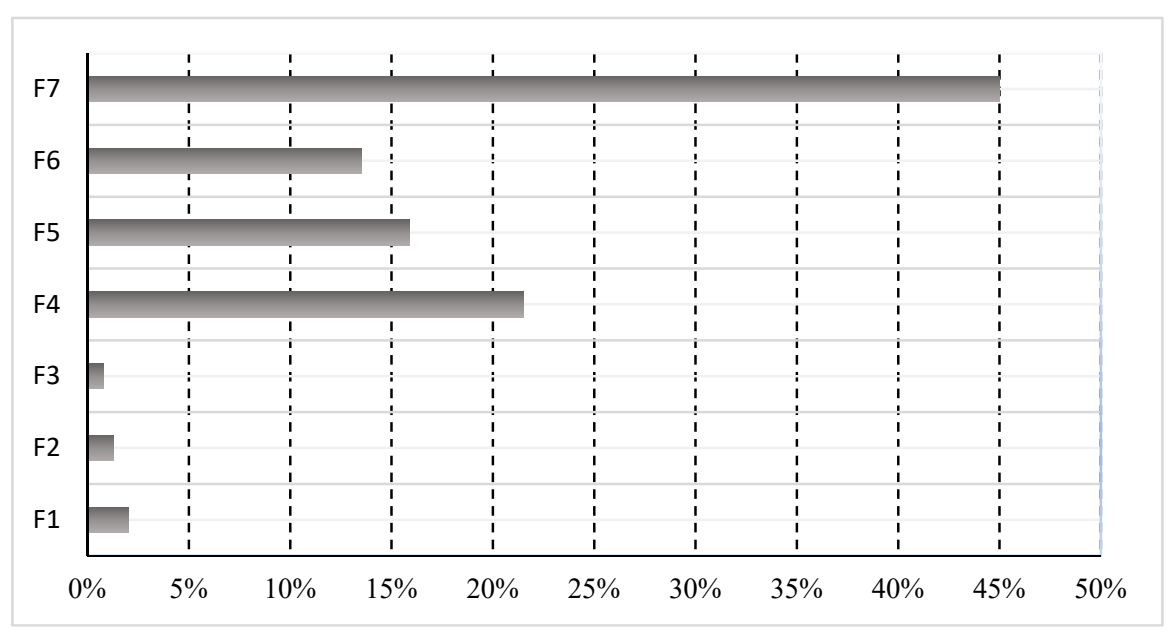

Figure 1. The percentage of cobalt fractions in sewage sludge. F1 = easily soluble; F2 = exchangeable; $\mathrm{F} 3=$ bound to $\mathrm{MnO}_{\mathrm{x}} ; \mathrm{F} 4=$ bound to organic matter; $\mathrm{F} 5=$ bound to amorphous $\mathrm{FeO}_{\mathrm{x}} ; \mathrm{F} 6=$ bound to crystalline $\mathrm{FeO}_{\mathrm{x}} ; \mathrm{F} 7=$ residual.

In the present incubation experiment, varied doses of sewage sludge and liming had a significant effect on the overall content of cobalt in the soil (Table 3). Throughout, the content of this metal in soil treated with different doses of sewage sludge was low and ranged from 0.949 to $2.87 \mathrm{mg} \mathrm{kg}^{-1}$ soil. The average content in the surface layer of Polish sandy soil is $2.63 \mathrm{mg} \mathrm{kg}^{-1}$, with $7.23 \mathrm{mg} \mathrm{kg}^{-1}$ in clay soil and luvisols and $3.0 \mathrm{mg} \mathrm{kg}^{-1}$ in organic soil $[15,42]$.

Table 3. Total content of cobalt $\left(\mathrm{mg} \mathrm{kg}^{-1}\right)$ in soil in the incubation experiment.

\begin{tabular}{|c|c|c|c|c|c|c|c|c|c|c|}
\hline \multirow{2}{*}{ Days } & 0 & $5 \%$ & $10 \%$ & $15 \%$ & Mean & 0 & $5 \%$ & $10 \%$ & $15 \%$ & Mean \\
\hline & \multicolumn{5}{|c|}{ Without Liming } & \multicolumn{5}{|c|}{ Liming } \\
\hline 30 & 1.02 & 1.68 & 2.33 & 2.76 & 1.95 & 0.999 & 1.52 & 2.41 & 2.87 & 1.95 \\
\hline 60 & 1.11 & 1.55 & 2.52 & 2.71 & 1.97 & 1.04 & 1.45 & 2.36 & 2.69 & 1.89 \\
\hline 90 & 1.03 & 1.69 & 2.74 & 2.87 & 2.08 & 1.10 & 1.36 & 2.71 & 2.59 & 1.94 \\
\hline 120 & 0.998 & 1.76 & 2.81 & 2.78 & 2.09 & 0.949 & 1.69 & 2.51 & 2.55 & 1.93 \\
\hline 360 & 0.987 & 1.74 & 2.68 & 2.71 & 2.03 & 0.955 & 1.54 & 2.66 & 2.78 & 1.98 \\
\hline 420 & 1.02 & 1.63 & 2.60 & 2.66 & 1.98 & 1.00 & 1.50 & 2.58 & 2.81 & 1.97 \\
\hline mean & 1.03 & 1.68 & 2.61 & 2.75 & 2.02 & 1.01 & 1.51 & 2.54 & 2.72 & 1.94 \\
\hline \multicolumn{11}{|c|}{$\mathrm{LSD}_{0.05}$ for: $\mathrm{A}=0.12 ; \mathrm{B}=0.065 ; \mathrm{C}=$ n.s.; $\mathrm{A} / \mathrm{B}=$ n.s.; $\mathrm{B} / \mathrm{A}=$ n.s.; $\mathrm{A} / \mathrm{C}=$ n.s. $\mathrm{C} / \mathrm{A}=$ n.s.; $\mathrm{B} / \mathrm{C}=$ n.s.; $\mathrm{C} / \mathrm{B}=$ n.s. } \\
\hline
\end{tabular}


On average, compared to the control, total content of cobalt in the soil increased more than two times in response to the two higher doses of sewage sludge (10 and 15\% of the weight of the soil). In the non-limed soil, it was, respectively, 2.61 and $2.75 \mathrm{mg} \mathrm{kg}^{-1}$ and 2.54 and $2.72 \mathrm{mg} \mathrm{kg}^{-1}$ in the limed soil. A similar trend of zinc accumulation in the soil treated with different doses of sewage sludge was noted by Kalembasa and Malinowska [43] and by Malinowska [33]. In a four-year experiment, Speir et al. [44] found increased concentration of $\mathrm{Cu}, \mathrm{Ni}$, and $\mathrm{Zn}$ in the soil with sewage sludge.

Seven step sequential analysis was used 30 days after sewage sludge application, and a small percentage of cobalt in the mobile fraction in the soil was found. Its amount increased with doses of sewage sludge, and it was significantly greater in the non-limed soil than in limed soil (Tables 4 and 5). Soil acidity has a significant impact on the transformation of heavy metals, in particular on their mobilization and immobilization and the resulting circulation of chemical elements in the environment, and thus on the productivity of agricultural ecosystems [39,45]. In the non-limed soil, treated with the largest dose of sludge (15\%), the sum of the easy soluble (F1) and exchangeable (F2) fractions accounted for $2.63 \%$ of cobalt, while in the limed soil it was $3.30 \%$. An upward trend was found in samples collected later. Thus, after 90 days, the share of mobile fractions of cobalt had increased almost twice.

Table 4. Percentage share of cobalt fractions in total content in soil in the incubation experiment.

\begin{tabular}{|c|c|c|c|c|c|c|c|c|}
\hline Fertilization Object & $F_{1}$ & $\mathrm{~F}_{2}$ & $F_{3}$ & $F_{4}$ & $\mathbf{F}_{5}$ & $F_{6}$ & $\mathrm{~F}_{7}$ & $\mathrm{pH}^{*}$ \\
\hline \multicolumn{9}{|c|}{30 days } \\
\hline \multicolumn{9}{|c|}{ without liming } \\
\hline control & 1.82 & 1.10 & 2.36 & 25.45 & 19.05 & 20.21 & 30.01 & 4.30 \\
\hline $5 \%$ & 1.81 & 0.991 & 1.35 & 28.00 & 20.03 & 15.01 & 32.81 & 4.55 \\
\hline $10 \%$ & 1.98 & 1.20 & 1.31 & 35.04 & 11.00 & 14.38 & 35.09 & 5.05 \\
\hline $15 \%$ & 2.09 & 1.21 & 1.34 & 37.01 & 10.60 & 10.80 & 37.01 & 5.17 \\
\hline mean & 1.93 & 1.13 & 1.59 & 31.38 & 15.17 & 15.10 & 33.73 & \\
\hline \multicolumn{9}{|c|}{ liming } \\
\hline control & 1.08 & 0.981 & 0.301 & 25.05 & 16.32 & 20.26 & 36.01 & 6.30 \\
\hline $5 \%$ & 1.40 & 0.995 & 0.309 & 32.01 & 18.94 & 14.51 & 31.84 & 6.32 \\
\hline $10 \%$ & 1.52 & 1.00 & 0.321 & 29.09 & 18.12 & 13.44 & 36.51 & 6.35 \\
\hline $15 \%$ & 1.55 & 1.08 & 0.311 & 28.95 & 19.37 & 10.70 & 38.04 & 6.48 \\
\hline mean & 1.39 & 1.01 & 0.311 & 28.78 & 18.19 & 14.73 & 35.60 & \\
\hline \multicolumn{9}{|c|}{60 days } \\
\hline \multicolumn{9}{|c|}{ without liming } \\
\hline control & 1.05 & 1.70 & 2.20 & 20.16 & 17.23 & 22.61 & 35.05 & 4.38 \\
\hline $5 \%$ & 2.59 & 1.95 & 2.93 & 25.11 & 17.96 & 20.72 & 28.84 & 4.80 \\
\hline $10 \%$ & 1.90 & 0.991 & 1.31 & 24.75 & 18.04 & 13.00 & 40.11 & 5.02 \\
\hline $15 \%$ & 1.52 & 1.02 & 2.31 & 27.04 & 17.00 & 10.05 & 41.08 & 5.00 \\
\hline mean & 1.77 & 1.42 & 2.19 & 24.27 & 17.56 & 16.60 & 36.27 & \\
\hline \multicolumn{9}{|c|}{ liming } \\
\hline control & 1.11 & 1.58 & 1.25 & 23.85 & 19.01 & 20.05 & 33.17 & 6.25 \\
\hline $5 \%$ & 1.38 & 0.709 & 1.39 & 30.49 & 18.88 & 17.20 & 29.95 & 6.30 \\
\hline $10 \%$ & 1.45 & 0.985 & 1.14 & 35.45 & 14.56 & 11.96 & 34.48 & 6.25 \\
\hline $15 \%$ & 1.80 & 0.846 & 1.85 & 36.21 & 12.15 & 11.08 & 36.08 & 6.50 \\
\hline mean & 1.44 & 1.03 & 1.41 & 31.50 & 16.15 & 15.07 & 33.42 & \\
\hline
\end{tabular}


Table 4. Cont

\begin{tabular}{|c|c|c|c|c|c|c|c|c|}
\hline Fertilization Object & $F_{1}$ & $F_{2}$ & $F_{3}$ & $F_{4}$ & $F_{5}$ & $F_{6}$ & $\mathbf{F}_{7}$ & $\mathrm{pH}^{*}$ \\
\hline \multicolumn{9}{|c|}{90 days } \\
\hline \multicolumn{9}{|c|}{ without liming } \\
\hline control & 2.60 & 2.05 & 1.21 & 21.05 & 14.02 & 29.07 & 30.01 & 4.26 \\
\hline $5 \%$ & 2.51 & 3.70 & 1.19 & 25.29 & 13.26 & 22.54 & 31.51 & 5.15 \\
\hline $10 \%$ & 2.85 & 3.00 & 2.24 & 25.06 & 18.45 & 19.41 & 29.00 & 5.10 \\
\hline $15 \%$ & 3.13 & 2.78 & 2.24 & 24.08 & 18.14 & 19.00 & 30.63 & 5.12 \\
\hline mean & 2.77 & 2.88 & 1.72 & 23.87 & 15.97 & 22.51 & 30.29 & \\
\hline \multicolumn{9}{|c|}{ liming } \\
\hline control & 2.21 & 1.55 & 1.22 & 22.50 & 15.20 & 28.90 & 28.42 & 6.25 \\
\hline $5 \%$ & 1.74 & 2.70 & 1.19 & 21.91 & 14.19 & 28.35 & 29.91 & 6.34 \\
\hline $10 \%$ & 2.11 & 2.69 & 2.05 & 28.08 & 17.36 & 18.96 & 28.72 & 6.40 \\
\hline $15 \%$ & 2.99 & 2.68 & 2.22 & 27.04 & 17.21 & 14.81 & 33.05 & 6.45 \\
\hline mean & 2.26 & 2.41 & 1.67 & 24.88 & 15.99 & 22.76 & 30.03 & \\
\hline \multicolumn{9}{|c|}{120 days } \\
\hline \multicolumn{9}{|c|}{ without liming } \\
\hline control & 1.75 & 1.30 & 0.918 & 23.00 & 14.01 & 30.11 & 29.01 & 4.30 \\
\hline $5 \%$ & 1.76 & 2.39 & 1.20 & 26.00 & 16.12 & 25.60 & 27.02 & 5.17 \\
\hline $10 \%$ & 2.80 & 2.70 & 3.19 & 21.56 & 18.23 & 24.72 & 26.80 & 5.20 \\
\hline $15 \%$ & 2.84 & 2.66 & 3.16 & 24.01 & 17.98 & 12.63 & 36.72 & 5.21 \\
\hline mean & 2.29 & 2.26 & 2.12 & 23.64 & 16.59 & 23.27 & 29.89 & \\
\hline \multicolumn{9}{|c|}{ liming } \\
\hline control & 1.50 & 1.49 & 1.11 & 25.00 & 20.41 & 19.99 & 30.50 & 6.31 \\
\hline $5 \%$ & 1.57 & 1.96 & 1.60 & 28.90 & 16.58 & 17.39 & 32.00 & 6.40 \\
\hline $10 \%$ & 1.70 & 1.60 & 1.18 & 25.42 & 16.01 & 23.05 & 31.04 & 6.45 \\
\hline $15 \%$ & 1.79 & 2.62 & 1.19 & 23.08 & 17.02 & 15.17 & 38.95 & 6.37 \\
\hline mean & 1.64 & 1.92 & 1.27 & 25.60 & 17.55 & 18.90 & 33.12 & \\
\hline
\end{tabular}

F $_{1}-\mathrm{LSD}_{0.05}$ for: $\mathrm{A}=0.357 ; \mathrm{B}=0.191 ; \mathrm{C}=0.357 ; \mathrm{A} / \mathrm{B}=0.504 ; \mathrm{B} / \mathrm{A}=0.387 ; \mathrm{C} / \mathrm{A}=$ n.s.; $\mathrm{A} / \mathrm{C}=$ n.s.; $\mathrm{C} / \mathrm{B}=$ n.s.; $\mathrm{B} / \mathrm{C}=$ n.s.; $\mathrm{F}_{2}-\mathrm{LSD}_{0.05}$ for: $\mathrm{A}=0.284 ; \mathrm{B}=0.152 ; \mathrm{C}=0.284 ; \mathrm{A} / \mathrm{B}=0.402 ; \mathrm{B} / \mathrm{A}=0.304 ; \mathrm{C} / \mathrm{A}=$ n.s.; $\mathrm{A} / \mathrm{C}=$ n.s.; $\mathrm{C} / \mathrm{B}=$ n.s.; $\mathrm{B} / \mathrm{C}=$ n.s..; $\mathrm{F}_{3}-\mathrm{LSD}_{0.05}$ for: $\mathrm{A}=0.157 ; \mathrm{B}=0.084 ; \mathrm{C}=0.157 ; \mathrm{A} / \mathrm{B}=0.222 ; \mathrm{B} / \mathrm{A}=0.168 ; \mathrm{C} / \mathrm{A}=0.222 ; \mathrm{A} / \mathrm{C}=0.222 ; \mathrm{C} / \mathrm{B}=0.222$; $\mathrm{B} / \mathrm{C}=0.168 . ; \mathrm{F}_{4}-\mathrm{LSD}_{0.05}$ for: $\mathrm{A}=0.304 ; \mathrm{B}=0.164 ; \mathrm{C}=0.304 ; \mathrm{A} / \mathrm{B}=0.430 ; \mathrm{B} / \mathrm{A}=0.326 ; \mathrm{C} / \mathrm{A}=0.430 ; \mathrm{A} / \mathrm{C}=0.430$; $\mathrm{C} / \mathrm{B}=0.430 ; \mathrm{B} / \mathrm{C}=0.326 ; \mathrm{F}_{5}-\mathrm{LSD}_{0.05}$ for: $\mathrm{A}=0.260 ; \mathrm{B}=0.139 ; \mathrm{C}=0.260 ; \mathrm{A} / \mathrm{B}=0.368 ; \mathrm{B} / \mathrm{A}=0.279 ; \mathrm{C} / \mathrm{A}=0.368$; $\mathrm{A} / \mathrm{C}=0.368 ; \mathrm{C} / \mathrm{B}=0.368 ; \mathrm{B} / \mathrm{C}=0.279 ; \mathrm{F}_{6}-\mathrm{LSD}_{0.05}$ for: $\mathrm{A}=0.310 ; \mathrm{B}=0.166 ; \mathrm{C}=0.310 ; \mathrm{A} / \mathrm{B}=0.438 ; \mathrm{B} / \mathrm{A}=0.332$ $\mathrm{C} / \mathrm{A}=0.438 ; \mathrm{A} / \mathrm{C}=0.438 ; \mathrm{C} / \mathrm{B}=0.438 ; \mathrm{B} / \mathrm{C}=0.332 ; \mathrm{F}_{7}-\mathrm{LSD}_{0.05}$ for: $\mathrm{A}=0.282 ; \mathrm{B}=0.151 ; \mathrm{C}=0.282 ; \mathrm{A} / \mathrm{B}=0.398$; $\mathrm{B} / \mathrm{A}=0.302 ; \mathrm{C} / \mathrm{A}=0.398 ; \mathrm{A} / \mathrm{C}=0.398 ; \mathrm{C} / \mathrm{B}=0.398 ; \mathrm{B} / \mathrm{C}=0.302 . \mathrm{A}=$ sewage dose; $\mathrm{B}=$ liming; $\mathrm{C}=$ days; $\mathrm{A} / \mathrm{B}$, $\mathrm{B} / \mathrm{A}, \mathrm{A} / \mathrm{C}, \mathrm{C} / \mathrm{A}, \mathrm{B} / \mathrm{C}, \mathrm{C} / \mathrm{B}=$ interaction; n.s. = not significant difference; $\mathrm{F} 1=$ easily soluble, $\mathrm{F} 2$ = exchangeable, $\mathrm{F} 3=$ bound to $\mathrm{MnO}_{\mathrm{x}}, \mathrm{F} 4=$ bound to organic matter, $\mathrm{F} 5=$ bound to amorphous $\mathrm{FeO}_{\mathrm{x}}, \mathrm{F} 6=$ bound to crystalline $\mathrm{FeO}_{x}, \mathrm{~F} 7=$ residual $; \%, 10 \%, 15 \%$ of sewage sludge to dry mass of soil. ${ }^{*}$ Malinowska [46].

Table 5. Percentage share of cobalt fractions in total content in soil in the incubation experiment.

\begin{tabular}{ccccccccc}
\hline Fertilization Objects & $\mathbf{F}_{\mathbf{1}}$ & $\mathbf{F}_{\mathbf{2}}$ & $\mathbf{F}_{\mathbf{3}}$ & $\mathbf{F}_{\mathbf{4}}$ & $\mathbf{F}_{\mathbf{5}}$ & $\mathbf{F}_{\mathbf{6}}$ & $\mathbf{F}_{\mathbf{7}}$ & $\mathbf{p H}^{*}$ \\
\hline \multicolumn{7}{c}{360 days } \\
\hline \multicolumn{7}{c}{ without liming } \\
\hline control & 2.50 & 2.30 & 2.19 & 18.80 & 12.96 & 39.45 & 21.79 & 4.40 \\
$5 \%$ & 1.60 & 1.38 & 1.11 & 24.20 & 10.25 & 31.57 & 29.89 & 4.80 \\
$10 \%$ & 1.63 & 1.40 & 0.325 & 28.91 & 13.69 & 23.05 & 31.00 & 5.15 \\
$15 \%$ & 1.68 & 1.50 & 0.500 & 30.42 & 13.44 & 18.47 & 34.05 & 5.05 \\
\hline mean & 1.85 & 1.65 & 1.04 & 25.58 & 12.59 & 28.14 & 29.18 & \\
\hline
\end{tabular}


Table 5. Cont.

\begin{tabular}{|c|c|c|c|c|c|c|c|c|}
\hline Fertilization Objects & $F_{1}$ & $F_{2}$ & $F_{3}$ & $F_{4}$ & $F_{5}$ & $F_{6}$ & $F_{7}$ & $\mathrm{pH}^{*}$ \\
\hline \multicolumn{9}{|c|}{ liming } \\
\hline control & 1.45 & 0.800 & 0.118 & 24.70 & 13.01 & 38.40 & 21.52 & 6.10 \\
\hline $5 \%$ & 1.45 & 1.311 & 0.310 & 27.00 & 12.69 & 28.24 & 29.00 & 6.25 \\
\hline $10 \%$ & 1.59 & 1.40 & 0.545 & 30.56 & 14.52 & 25.74 & 25.65 & 6.28 \\
\hline $15 \%$ & 1.60 & 1.41 & 0.630 & 32.86 & 14.03 & 25.47 & 24.00 & 6.35 \\
\hline mean & 1.52 & 1.23 & 0.401 & 28.78 & 13.56 & 29.46 & 25.04 & \\
\hline \multicolumn{9}{|c|}{420 days } \\
\hline \multicolumn{9}{|c|}{ without liming } \\
\hline control & 1.35 & 1.14 & 0.101 & 23.00 & 11.23 & 43.13 & 20.05 & 4.35 \\
\hline $5 \%$ & 1.40 & 1.20 & 0.341 & 20.50 & 12.03 & 37.53 & 27.00 & 4.90 \\
\hline $10 \%$ & 1.45 & 1.24 & 0.552 & 29.00 & 12.45 & 34.60 & 20.71 & 5.20 \\
\hline $15 \%$ & 2.47 & 2.20 & 0.450 & 29.42 & 11.56 & 22.84 & 31.06 & 5.08 \\
\hline mean & 1.57 & 1.45 & 0.361 & 25.48 & 11.82 & 34.53 & 24.71 & \\
\hline \multicolumn{9}{|c|}{ liming } \\
\hline control & 1.20 & 0.901 & 0.100 & 25.00 & 11.02 & 40.78 & 21.00 & 6.00 \\
\hline $5 \%$ & 1.33 & 1.19 & 0.250 & 35.09 & 14.11 & 27.94 & 20.09 & 6.30 \\
\hline $10 \%$ & 1.39 & 1.20 & 0.356 & 30.01 & 12.36 & 29.61 & 25.07 & 6.18 \\
\hline $15 \%$ & 1.89 & 1.82 & 0.273 & 45.68 & 13.02 & 9.27 & 28.05 & 6.28 \\
\hline mean & 1.45 & 1.28 & 0.245 & 33.95 & 12.63 & 26.90 & 23.55 & \\
\hline \multicolumn{9}{|c|}{ 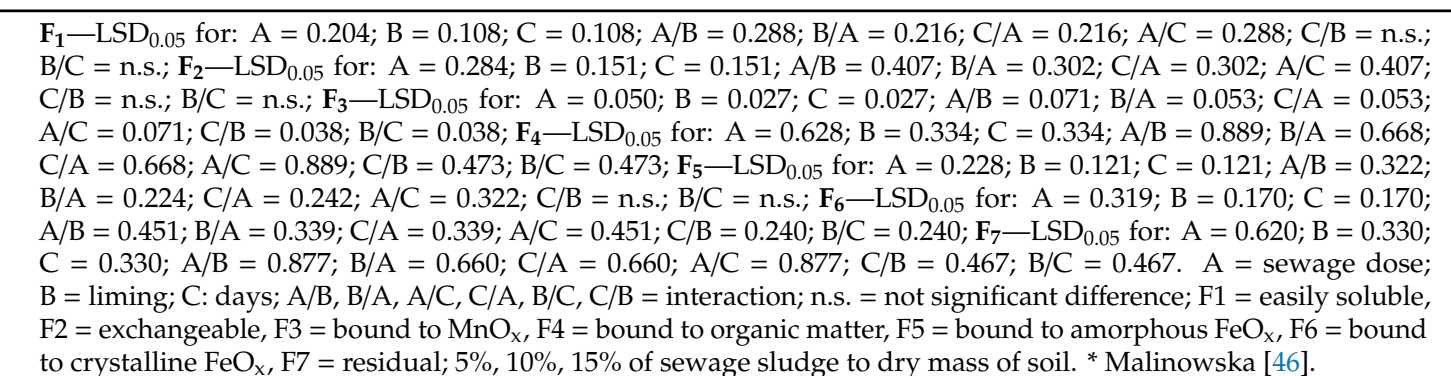 } \\
\hline
\end{tabular}

Throughout the experiment, the largest percentage of this metal in the soil was recorded in the residual (F7) and organic (F4) fractions. Within 120 days, the percentage of cobalt in the residual fraction was dominant and represented more than $30 \%$ almost in all units. In the subsequent periods of the research, this participation was reduced. The amount of cobalt bound to organic matter was greater in limed soil than in the soil without liming, with the exception of samples collected after 30 days. The relationship between soil $\mathrm{pH}$ and the amount of metals bound to organic matter was confirmed by the research of Domańska [47] and Malinowska [46]. On the 420th day, the percentage of cobalt in the organic fraction increased, compared to the start of the experiment. At the end of the experiment, there was also a marked increase in the amount of cobalt bound to organic matter as a response to increasing doses of sewage sludge. Bhattacharyya et al. [39] found that the amounts of cobalt in alluvial soils decreased in the following order: organic-bound; Fe and Mn oxide-bound; residual; exchangeable; carbonate-bound; soluble in water. Zhai et al. [48] reported the dominance of Fe and Mn oxide-bound cobalt in soil, accounting for $23-35 \%$, while $4-20 \%$ was organic bound.

According to many authors [45,49], acidity is one of the most important properties of the soil, determining the course of many of its processes. It affects organic metabolism, the assimilation of heavy metals, and the development of microorganisms, affecting the yield of plants.

In turn, the average percentage of cobalt bound to crystalline iron oxides (F6) in the soil collected in different periods was higher in non-limed than in limed soil, as opposed to cobalt bound to amorphous FeOx (F5), the content of which was higher in limed soil. Starting with the 90th day, there was a 
statistically significant higher increase in the share of cobalt bound to crystalline $\mathrm{FeOx}$ than that bound to amorphous FeOx. At the end of the experiment, after 420 days, there was a several fold decrease in the percentage of cobalt bound to manganese oxides (F3), compared to the soil collected after 30 days. Based on statistical analysis of non-limed soil, it was found that there was a positive correlation (Table 6) between soil $\mathrm{pH}$, total content of cobalt, and the amount of this metal bound to organic matter (F4) and a significant negative correlation between $\mathrm{pH}$, total cobalt content, and the amount of this metal bound to crystalline $\mathrm{FeOx}$ (F6). In non-limed soil, there was also a significant positive correlation between total content of cobalt and the content of this metal in the residual fraction (F7).

Table 6. Linear correlation coefficient between soil $\mathrm{pH}$, total cobalt content, and its content in fractions.

\begin{tabular}{ccccc}
\hline \multirow{2}{*}{ Fraction } & \multicolumn{2}{c}{$\mathbf{p H}$} & \multicolumn{2}{c}{ Co } \\
\cline { 2 - 5 } & $-\mathbf{C a}$ & $+\mathbf{C a}$ & $-\mathbf{C a}$ & $+\mathrm{Ca}$ \\
\hline F1 & 0.279 & $0.460^{*}$ & 0.304 & $0.432 *$ \\
F2 & -0.223 & 0.374 & -0.236 & 0.251 \\
F3 & 0.037 & $0.564^{*}$ & 0.100 & 0.201 \\
F4 & $0.489 *$ & 0.138 & $0.535^{*}$ & $0.503^{*}$ \\
F5 & -0.037 & $0.453^{*}$ & 0.081 & -0.072 \\
F6 & $-0.425 *$ & $-0.719^{*}$ & $-0.568^{*}$ & $-0.513^{*}$ \\
F7 & 0.257 & $0.634^{*}$ & $0.405^{*}$ & 0.265 \\
\hline
\end{tabular}

$p \leq 0.05 ;-\mathrm{Ca}=$ without liming; $+\mathrm{Ca}=$ liming; ${ }^{*}=$ significant difference; $\mathrm{F} 1=$ easily soluble; $F 2$ = exchangeable; $\mathrm{F} 3=$ bound to $\mathrm{MnO}_{\mathrm{x}} ; \mathrm{F} 4=$ bound to organic matter; $\mathrm{F} 5=$ bound to amorphous $\mathrm{FeO}_{\mathrm{x}} ; \mathrm{F} 6$ = bound to crystalline $\mathrm{FeO}_{\mathrm{x}}$; F7 = residual.

In the limed soil, there was a statistically significant positive correlation between $\mathrm{pH}$ and the content of cobalt bound to $\mathrm{MnOx}$ (F3) between $\mathrm{pH}$ and the amount of cobalt bound to amorphous FeOx (F5) and between $\mathrm{pH}$ and the amount of the metal bound to the residual (F7) fraction. Additionally, there was a negative correlation between $\mathrm{pH}$ and the amount of cobalt bound to crystalline FeOx (F6). Total content of cobalt was significantly positively correlated with its amount in the organic fraction (F4) and negatively with the crystalline FeOx fraction (F6). According to Kalembasa and Malinowska [43] and Laudicina et al. [50], liming and the type and amount of organic substance had a significant impact on forms of heavy metals in the soil. It was confirmed by high values of linear correlation coefficients. In their research, Bakkaus et al. [51] found no relationship between exchangeable cobalt content and total Mn and Fe content in soil.

On the basis of detailed 420 days of the studies, with various doses of sewage sludge added to the soil, it was found that residual (F7) and iron oxide-bound (F5 and F6) cobalt was dominant, indicating the possibility of agricultural and natural use of this waste. According to McLaren et al. [41], cobalt bound to oxides is low in bioavailability (sorption is strong). Pinkerton and Brown [52] reported that, even after cobalt salts were introduced into the soil, there was no increase in its accumulation by plants.

\section{Conclusions}

1. Percentage of cobalt fractions in municipal sewage sludge can be arranged in a series of increasing percentages: $\mathrm{F} 3(0.80)<\mathrm{F} 2(1.30)<\mathrm{F} 1(2.00)<\mathrm{F} 6(13.5)<\mathrm{F} 5(15.9)<\mathrm{F} 4(21.50)<\mathrm{F} 7(45.0)$.

2. In the incubation experiment, varied sewage sludge doses had a significant effect on total content of cobalt in the soil. Its amounts increased with higher doses of sewage sludge.

3. The percentage of cobalt in separate fractions in the soils of different experimental units was dependent on the dose of sewage sludge and liming. On average, compared to the control, cobalt content increased more than two times as a response to higher doses of sewage sludge (10 and $15 \%$ of the weight of the soil).

4. Compared to the beginning of the experiment, increasing doses of sewage sludge increased the percentage of cobalt in the organic fraction (F4) after 420 days of soil incubation, while, at the same 
time, the percentage share of this chemical element bound to manganese oxides (F3) decreased a few times.

5. Based on the experiment, it was concluded that the chemical speciation of cobalt is not a permanent phenomenon and that it can be redistributed between the fractions, depending on $\mathrm{pH}$ of the soil and its organic matter content.

Author Contributions: Conceptualization, K.J.; methodology, E.M.; writing—original draft preparation, K.J.; writing - review and editing, E.M. All authors have read and agreed to the published version of the manuscript. All authors have equally contributed to this article.

Funding: The results of the research carried out under the research theme No.40/B/20 were financed from the science grant, granted by the Ministry of Science and Higher Education.

Conflicts of Interest: The authors declare no conflict of interest.

\section{References}

1. Statistical Yearbook of the Regions-Poland, Statistics Poland, Warsaw. 2019. Available online: http: //stat.gov.pl (accessed on 23 September 2020).

2. Waste Act of December 14, 2012 (Dz.U. Nr 0, poz. 21). Available online: http://isap.sejm.gov.pl (accessed on 10 September 2020).

3. Antolin, M.; Pascual, I.; Garcia, C.; Polo, A.; Schanez-Diaz, M. Growth, yield and solute content of barley in soils treated with sewage sludge under semiarid Mediterranean conditions. Field Crops Res. 2005, 94, 224-237. [CrossRef]

4. De Brouwere, K.; Smolders, E. Yield response of crops amended with sewage sludge in the field is more affected by sludge properties than by final soil metal concentration. Eur. J. Soil Sci. 2006, 57, 858-867. [CrossRef]

5. Diacono, M.; Montemurro, F. Long-term effects of organic amendments on soil fertility. A review. Agron. Sustain. Dev. 2010, 30, 401-422. [CrossRef]

6. Wong, J.W.; Li, K.; Fang, M.; Su, D.C. Toxicity evaluation of sewage sludges in Hong Kong. Environ. Int. 2001, 27, 373-380. [CrossRef]

7. Álvarez, E.; Mochón, M.C.; Sanchez, J.; Rodríguez, M. Heavy metal extractable forms in sludge from wastewater treatment plants. Chemosphere 2002, 47, 765-775. [CrossRef]

8. Hillman, J.P.; Hill, J.; Morgan, J.E.; Wilkinson, J.M. Recycling of sewage sludge to grassland: A review of the legislation to control of the localization and accumulation of potential toxic metals in grazing systems. Grass Forage Sci. 2003, 58, 101-111. [CrossRef]

9. Gupta, A.K.; Sinha, S. Phytoextraction capacity of the plants growing on tannery sludge dumping sites. Bioresour. Technol. 2007, 98, 1788-1794. [CrossRef] [PubMed]

10. Gawdzik, J.I. Speciation of heavy metals in sewage sludge: A case study. Ochr. Śr. 2010, 32, 15-19.

11. Gasco, G.; Martinez-Inigo, M.; Lobo, M. Soil organic matter transformation after a sewage sludge application. EJEAFChe 2004, 3, 716-722.

12. Czechowska-Kosacka, A. Influence of sewage sludge solidification on immobilisation of heavy metals. Polish J. Environ. Stud. 2007, 16, 625-628.

13. Hargreaves, J.; Adl, M.; Warman, P. A review of the use of composted municipal solid waste in agriculture. Agric. Ecosyst. Environ. 2008, 123, 1-14. [CrossRef]

14. Pshinko, G.N. Impact of complexing agents on the processes of sorption treatment of waters containing cobalt. J. Water Chem. Technol. 2008, 30, 197-202. [CrossRef]

15. Kabata-Pendias, A.; Pendias, H. Biogeochemistry of Trace Elements; Polish Scientific Publishing Company: Warsaw, Poland, 1999; p. 400.

16. Cappuyns, V.; Mallaerts, T. Background values of cobalt in Flemish and European soils. Geol. Belg. 2014, $17,107-114$.

17. Dahlin, S.; Witter, E.; Martensson, A.; Turner, A.; Baath, E. Where's the limit? Changes in the microbiological properties of agricultural soils at low levels of metal contamination. Soil Biol. Biochem. 1997, 29, 1405-1415. [CrossRef] 
18. McBride, M.B.; Richards, B.K.; Steenhuis, T.; Spiers, G. Long-term leaching of trace elements in a heavily sludge-amended silty clay loam soil. Soil Sci. 1999, 164, 613-623. [CrossRef]

19. Kirkland, D.; Brock, T.; Haddouk, H.; Hargeaves, V.; Lloyd, M.; Mc Garry, S.; Proudlock, R.; Sarlang, S.; Sewald, K.; Sire, G.; et al. New investigations into the genotoxicity of cobalt compounds and their impact on overall assessment of genotoxic risk. Regul. Toxicol. Pharmacol. 2015, 73, 311-338. [CrossRef]

20. Merrington, G.; Oliver, I.W.; Smernik, R.J.; McLaughlin, M. The influence of sewage sludge properties on sludge-borne metal availability. Adv. Environ. Res. 2003, 8, 21-36. [CrossRef]

21. Andersen, M.K.; Raulund-Rasmussen, K.; Hansen, H.C.B.; Strobel, B.W. Distribution and fractionation of heavy metals in pairs of arable and afforested soils in Denmark. Eur. J. Soil Sci. 2002, 53, 491-502. [CrossRef]

22. Gleyzes, C.; Tellier, S.; Astruc, M. Fractionation studies of trace elements in contaminated soils and sediments: A review of sequential extraction procedures. TrAC Trends Anal. Chem. 2002, 21, 451-467. [CrossRef]

23. Amir, S.; Hafidi, M.; Merlina, G.; Revel, J.-C. Sequential extraction of heavy metals during composting of sewage sludge. Chemosphere 2005, 59, 801-810. [CrossRef]

24. Wang, C.; Hu, X.; Chen, M.-L.; Wu, Y.-H. Total concentrations and fractions of Cd, Cr, Pb, Cu, Ni and $\mathrm{Zn}$ in sewage sludge from municipal and industrial wastewater treatment plants. J. Hazard. Mater. 2005, 119, 245-249. [CrossRef] [PubMed]

25. Jamali, M.K.; Kazi, T.G.; Afridi, H.I.; Arain, M.B.; Jalbani, N.; Memon, A.R. Speciation of heavy metals in untreated domestic wastewater sludge by time saving BCR sequential extraction method. J. Environ. Sci. Health Part A 2007, 42, 649-659. [CrossRef] [PubMed]

26. Rao, C.R.M.; Sahuquillo, A.; López-Sánchez, J. A Review of the Different Methods Applied in Environmental Geochemistry for Single and Sequential Extraction of Trace Elements in Soils and Related Materials. Water Air Soil Pollut. 2007, 189, 291-333. [CrossRef]

27. Mench, M.; Tancogne, J.; Gómez, A.; Juste, C. Cadmium bioavailability to Nicotiana tabacum L., Nicotiana rustica L., and Zea mays L. grown in soil amended or not amended with cadmium nitrate. Biol. Fertil. Soils 1989, 8, 48-53. [CrossRef]

28. Kaplan, M.; Orman, Ş.; Kádár, I.; Koncz, J. Heavy metal accumulation in calcareous soil and sorghum plants after addition of sulphur-containing waste as a soil amendment in Turkey. Agric. Ecosyst. Environ. 2005, 111, 41-46. [CrossRef]

29. Regulations of the Minister for Environment on soil quality standards and quality standards land 2002. Dz.U. Nr 165, poz. 1359. Available online: http://isap.sejm.gov.pl (accessed on 1 September 2020).

30. Regulations of the Minister for Environment in question sewage sludge 2010. Dz.U. Nr 137, poz. 924. Available online: http://isap.sejm.gov.pl (accessed on 10 September 2020).

31. Zeien, H.; Brümmer, G.W. Chemische Extraction zur Bestimmung von Schwermetallbindungsformen in Böden. Mittelign Dtsch Bodenkundl Gesellsch 1989, 59, 505-510.

32. STATISTICA (Data Analysis Software System); Version 10; StatSoft, Inc.: Palo Alto, CA, USA, 2011; Available online: www.statsoft.com (accessed on 1 September 2020).

33. Bojakowska, I.; Dobek, P.; Wołkowicz, S. Impact of biological wastewater treatment ponds on the ground environment. Gór. Ekol. 2012, 7, 59-69.

34. Malinowska, E. Zinc speciation in soil under various rates of sewage sludge and liming. Environ. Prot. Eng. 2016, 42, 5-15. [CrossRef]

35. Malinowska, E. The effect of liming and sewage sludge application on heavy metal speciation in soil. Bull. Environ. Contam. Toxicol. 2017, 98, 105-112. [CrossRef]

36. Atkins, P.; Jones, L. Chemia Ogólna. Czasteczki, Materia, Reakcje (Chemistry: Molecules, Matter, and Change); W. H. Freeman and Company: New York City, NY, USA, 2019.

37. Bożym, M.; Rajmund, A. The study of cobalt leaching from soils, sewage sludges and composts using a one-step extraction. Environ. Prot. Nat. Resour. 2015, 26, 1-6. [CrossRef]

38. Wang, C.; Li, X.; Wang, P.; Zou, L.-M.; Ma, H.-T. Extractable Fractions of Metals in Sewage Sludges from Five Typical Urban Wastewater Treatment Plants of China. Pedosphere 2006, 16, 756-761. [CrossRef]

39. Bhattacharyya, P.; Chakrabarti, K.; Chakraborty, A.; Tripathy, S.; Kim, K.; Powell, M.A. Cobalt and nickel uptake by rice and accumulation in soil amended with municipal solid waste compost. Ecotoxicol. Environ. Saf. 2008, 69, 506-512. [CrossRef] [PubMed] 
40. Greinert, A. Kobalt w Środowisku Przyrodniczym i Antropogenicznym (Cobalt in the Natural and Anthropogenic Environment), 1st ed.; Oficyna Wydawnicza Uniwersytetu Zielonogórskiego: Zielona Góra, Poland, 2011; p. 134. ISBN 978-83-7481-437-9.

41. McLaren, R.G.; Lawson, D.M.; Swift, R.S. Sorption and desorption of cobalt by soils and soil components. J. Soil Sci. 1986, 37, 413-426. [CrossRef]

42. Czarnowska, K. Total content of heavy metals in parent rocks as references background levels of soils. Soil Sci. Ann. 1996, 47, 43-50.

43. Kalembasa, D.; Malinowska, E. Bioaccumulation of zinc under the influence of sewage sludge and liming and its speciation in soil. Fresenius Environ. Bull. 2013, 22, 3359-3369.

44. Speir, T.W.; Van Schaik, A.P.; Percival, H.J.; Close, M.E.; Pang, L.P. Heavy metals in soil, plants and groundwater following high-rate sewage sludge application to land. Water Air Soil Pollut. 2003, 150, 319-358. [CrossRef]

45. Filipek, T.; Skowrońska, M. Current dominant causes and effects of acidification of soils under agricultural use in Poland. Acta Agrophys. 2013, 20, 283-294.

46. Malinowska, E. The effects of soil liming and sewage sludge application on dynamics of cooper fractions and total cooper concentration. Environ. Monit. Assess. 2017, 188, 597. [CrossRef]

47. Domańska, J. Changes of the content of total and extractable forms of lead $(\mathrm{Pb})$ in soil affected by organic matter and lime. Adv. Agric. Sci. Prob. 2006, 512, 91-97.

48. Zhai, M.; Kampunzu, H.A.B.; Modisi, M.P.; Totolo, O. Distribution of heavy metals in Gaborone urban soils (Botswana) and its relationship to soil pollution and bedrock composition. Environ. Earth Sci. 2003, 45, 171-180. [CrossRef]

49. Blake, L.; Goulding, K.; Mott, C.J.B.; Johnston, A. Changes in soil chemistry accompanying acidification over more than 100 years under woodland and grass at Rothamsted Experimental Station, UK. Eur. J. Soil Sci. 1999, 50, 401-412. [CrossRef]

50. Laudicina, V.A.; Palazzolo, E.; Badalucco, L. Natural Organic Compounds in Soil Solution: Potential Role as Soil Quality Indicators. Curr. Org. Chem. 2013, 17, 2991-2997. [CrossRef]

51. Bakkaus, E.; Gouget, B.; Gallien, J.-P.; Khodja, H.; Carrot, F.; Morel, J.; Collins, R. Concentration and distribution of cobalt in higher plants: The use of micro-PIXE spectroscopy. Nucl. Instrum. Methods Phys. Res. Sect. B Beam Interact. Mater. At. 2005, 231, 350-356. [CrossRef]

52. Pinkerton, B.W.; Brown, K.W. Plant Accumulation and Soil Sorption of Cobalt from Cobalt-Amended Soils1. Agron. J. 1907, 77, 634-638. [CrossRef]

(C) 2020 by the authors. Licensee MDPI, Basel, Switzerland. This article is an open access article distributed under the terms and conditions of the Creative Commons Attribution (CC BY) license (http://creativecommons.org/licenses/by/4.0/). 